Available online on 15.10 .2020 at http://jddtonline.info
Open Access to Pharmaceutical and Medical Research
unrestricted non-commercial use, provided the original work is properly cited

Open $\odot$ Access

Research Article

\title{
Isolation and Screening of Fungal Culture Isolated From Algerian Soil for the Production of Cellulase and Xylanase
}

\author{
Ouahiba GAHFIF', Yasmina SOUAGUI ${ }^{1}$, Zahra AZZOUZ ${ }^{2}$, Sadrati NOUARI ${ }^{1}$, Zahir AMGHAR ${ }^{2}$, Nawel \\ BOUCHERBA $^{2}$, Mouloud KECHA ${ }^{2}$, Said BENALLAOUA ${ }^{2}$, Azzeddine BETTACHE*2 \\ ${ }^{1}$ Laboratory of Characterization, Valorization of Natural Resources, University Mohamed El Bachir El Ibrahimi, Bordj Bou-Arreridj, Algeria \\ ${ }^{2}$ Laboratoire de Microbiologie Appliquée, faculté des Sciences de la Nature et de la Vie, université de Bejaia, 06000 B ejaia, Algeria
}

\begin{abstract}
Lignocellulolytic enzymes constitute a very large group of extracellular proteins secreting by fungi who is ecologically involved in the degradation of a variety of complex materials, a property that is attributed to a battery of enzymes produced by these microorganisms like cellulases and xylanases who are of significant industrial value and relevance. Forty fungal isolated from rich soil in organic matter were screened for lignocellulolytic enzymes production, its organized on the basis of their hydrolytic potential of cellulose and xylan. The isolates strains presented enzymatic activity which was ranked as follows: cellulolytic (56\%), xylanolytic $(44 \%)$. Some selected strains that produce high levels of enzymes (cellulase, xylanase) grown in submerged fermentation (SmF) and were quantitatively evaluated. The fer mentation experiments were carried out in shake flasks. The highest CMCase $(5,10 \mathrm{IU} / \mathrm{ml})$ and xylanase $(98,25 \mathrm{IU} / \mathrm{ml})$ activities were obtained from Trichoderma sp strain Mtr6 isolate.
\end{abstract}

Keywords: Fungi, Trichoderma sp, lignocellulolytic enzymes, soil, screening, organic matter.

Article Info: Received 17 Aug 2020; $\quad$ Review Completed 22 Sep 2020; $\quad$ Accepted 29 Sep 2020; Available online 15 Oct 2020

Cite this article as:

Gahfif O, Souagui Y, Azzouz Z, Nouari S, Amghar Z, Boucherba N, Kecha M, Benallaoua S, Bettache A, Isolation and Screening of Fungal Culture Isolated From Algerian Soil for the Production of Cellulase and Xylanase, Journal of Drug Delivery and Therapeutics. 2020; 10(5-s):108-113 http://dx.doi.org/10.22270/jddt.v10i5-s.4493

*Address for Correspondence:

Azzeddine BETTACHE, Laboratoire de Microbiologie Appliquée, faculté des Sciences de la Nature et de la Vie, université de Bejaia, 06000 Bejaia, Algeria

\section{INTRODUCTION}

Lignocellulose biomass is abundant in nature, and represents more than half of the organic matter produced globally via plant photosynthesis. Bioconversion of relatively inexpensive lignocellulosic biomass into biofuels and valueadded products can effectively alleviate pressure of energy supply and benefit sustainable development ${ }^{1}$. Lignocellulolytic microorganisms, especially fungi, have attracted a great deal of interest as biomass degraders for large-scale applications due to their ability to produce large amounts of extracellular lignocellulosic enzymes ${ }^{2}$. Enzymatic hydrolysis is an important technical, but expensive step in the process to obtain enzyme derived products. Thus, the production of efficient enzymes is of great interest for this biotechnological application ${ }^{3}$. Indeed, for the production of industrially important enzymes, such as different proteases, carbohydrases and lypases; fungi isolated from soil are known to be potential candidates ${ }^{5}$. According to Tasia and Melliawati 6 , microbial proteins are often more stable than those from other source, such as animal or plant origins, for this reason the industrial enzymes market prefers microbial enzymes?.

Microorganisms can be easily cultured in large quantities in a very short period of time. Fungi in particular are preferred for enzyme production, since they grow easily in a diversity of substrates and the large-scale production of enzyme is a relatively easy process in biotechnological industries. Therefore, commercial enzymes that are on the market are often of fungal origin, including cellulases and xylanase ${ }^{8}$. These two groups of enzymes have numerous application and massive biotechnological potentials for the various industrial sectors, including chemical, food, brewer and wine, animal feed, textile and laundry, pulp, paper and agriculture $8,9,10,11$ and are currently being used significantly in the commercial bioconversion of lignocellulosic biomass to bioethanol ${ }^{12}$.

Submerged fermentation ( $\mathrm{SmF}$ ) has been traditionally used for the production of industrially important enzymes because of the ease of handling and greater control of environmental factors such as temperature and $\mathrm{pH}^{13}$. Many 
researchers studied about extracellular enzyme by microorganisms from many sources $14,15,16,17,18,19$. The aim of this study was to select fungi from soil or decomposing organic material for the production of two industrially important extracellular lignocellulolytic enzymes: cellulase and xylanase using solid media screening and liquide media assays, as well as to access the enzymatic activity of most promising isolates.

\section{MATERIALS AND METHODS}

\section{Isolation of fungi from soil}

The fungi used in this study were collected from soil samples of rich organic matter from several regions of Algeria (Mascara from the West, and Bordj Bou Arrerridj from the East) within a depth of 5 to $10 \mathrm{~cm}$ after removal of superficial layer. Serial dilution method was carried out for isolation of pure culture. The isolates were further inoculated on sterile PDA (potato dextrose agar) plates and incubated at $28^{\circ} \mathrm{C}$ for 3-5 days. These fungi were then subcultured and preserved in pure form. Colonial morphology and microscopic examinations of the various isolates of pure cultures were used to determine the reproductive and vegetative structures 20 .

\section{Screening of fungal for lignocellulolytic enzymes production}

First screening was done by qualitative method (agar plate method, hydrolysis zone) and second screening method (liquid culture). Lignocellulolytic enzyme activity was tested on solid media for all the isolated cultures. Strains whose result positive in first screening were tested on liquid media (quantitative screening).

\section{Enzymatic assays in solid media (first screening)}

Enzymes production is sought qualitatively on solid medium. Fungal strains were screened for cellulase and xylanase. Solid culture media containing targeted substrates as a single source of carbon and energy; $1 \%$ for each substrate used and $1.8 \%(\mathrm{v} / \mathrm{w})$ agar.

Cellulolytic and xylanolytic activities: The culture medium described by Mandeles and Weber ${ }^{21}$ was used to study the ability of the fungal isolates to produce cellulase and xylanase using $1 \%$ of carboxymethyl cellulose (CMC) and birchwood respectively. When the colony diameter was approximately $30 \mathrm{~mm}$, the plates were flooded with $0.25 \%$ $\mathrm{w} / \mathrm{v}$ aqueous iodine (I2 and $\mathrm{KI}$ ) and left for 15 minutes, then poured off the staining material and washed the agar surface with distilled water. Then, the plates were flooded with $1 \mathrm{M}$ $\mathrm{NaCl}$ to distain for 5 minutes and then the distaining fluid was poured off. The hydrolysis zone of cellulose appeared as a clear zone around the colony ${ }^{19}$. Xylan degradation around the colonies appeared as a yellow-opaque area against a blue/reddish purple color for undegraded xylan ${ }^{22}$.

Mediums are autoclaved and inoculated with agar blocks (6 $\mathrm{mm}$ in diameter) from one-week old fungal colony grown on PDA plates in the center of the medium's plates. The plates were incubated at $28{ }^{\circ} \mathrm{C}$ for 5 or 7 days. After incubation, activities were revealed by the appearance of a ring-shaped clear zone surrounding colony growth.
Production of lignocellulolytic enzyme using liquid culture (quantitative screening)

The production of hydrolytic enzymes (cellulase and xylanase) is carried out in $250 \mathrm{ml}$ Erlenmeyer flasks, containing $50 \mathrm{ml}$ of the liquid culture medium. To obtain hydrolytic enzymes the fungi were grown in this medium with $1 \%$ of substrate (wheat bran) for cellulase and xylanase activity, and then sterilized by autoclaving at $121^{\circ} \mathrm{C}$ for 15 min before inoculation. Inoculum in the form of mycelia disc is prepared by cutting the agar plug from the periphery of the actively grown fungi 23 .

Mycelium disks (6mm in diameter) were excised from PDA plates and used to inoculate the contents of Erlenmeyer flasks. The culture was incubated in shaking incubator for 7 days at $28 \mathrm{C}^{\circ}$, after incubation it was filtered using Whatman no.1 filter paper, the filtrates were centrifuged at $10000 \mathrm{~g}$ for $15 \mathrm{~min}$ at $4^{\circ} \mathrm{C}$. The clear supernatants were used as the crude extracellular enzyme's sources ${ }^{24}$.

\section{Determination of enzymes activities}

\section{Cellulase and xylanase activities}

According to Ghose (1987) ${ }^{25}$, endoglucanase and xylanase activities were determined using DNS (3,5-dinitro salicylic acid) using carboxymethyl cellulose and birchwood xylan at $(2 \%)$ as substrates in sodium citrate buffer ( $50 \mathrm{mM}, \mathrm{pH} 4.8)$. The reaction mixture contained $0.5 \mathrm{ml}$ of culture filtrate and $0.5 \mathrm{ml}$ substrate was incubated at $50^{\circ} \mathrm{C}$ for $30 \mathrm{~min}$ for enzymatic reaction.

The liberated reducing sugars (glucose/ xylose) were measured by 3,5-dinitrosalicylic acid (DNS) method of Miller (1959)26. Absorbance of the solution was measured at 540 $\mathrm{nm}$ using UV-VIS spectrophotometer. One international unit was defined as the amount of enzyme which liberates $1 \mu \mathrm{mol}$ of reducing sugar per milliliter per minute under the given assay conditions.

\section{Statistical methods}

Data obtained were statistically analyzed using variance analysis of (ANOVA) Microsoft EXCEL 2016.

\section{RESULT AND DISCUSSION}

According to Jahangeer et al (2005) ${ }^{15}$ fungi are well-known as agents of decomposition of organic matter in general and lignocellulosic substrate in particular by secreting cellulases and xylanases who are a key enzyme that can be effectively used to solve challenges associated with energy inadequacy and environmental pollution ${ }^{27}$.

Qualitative tests are powerful tools and particularly useful in screening large numbers of fungal isolates for several classes of enzyme ${ }^{22}$.

The fourty fungal isolates used in qualitative tests were isolated from rich soil in organic matter and were submitted to the hydrolytic tests to confirm the production of cellulase and xylanase. The results for the qualitative assays performed on solid media for the production of hydrolytic enzymes by fungi are presented in figure 1 and table 1 . 

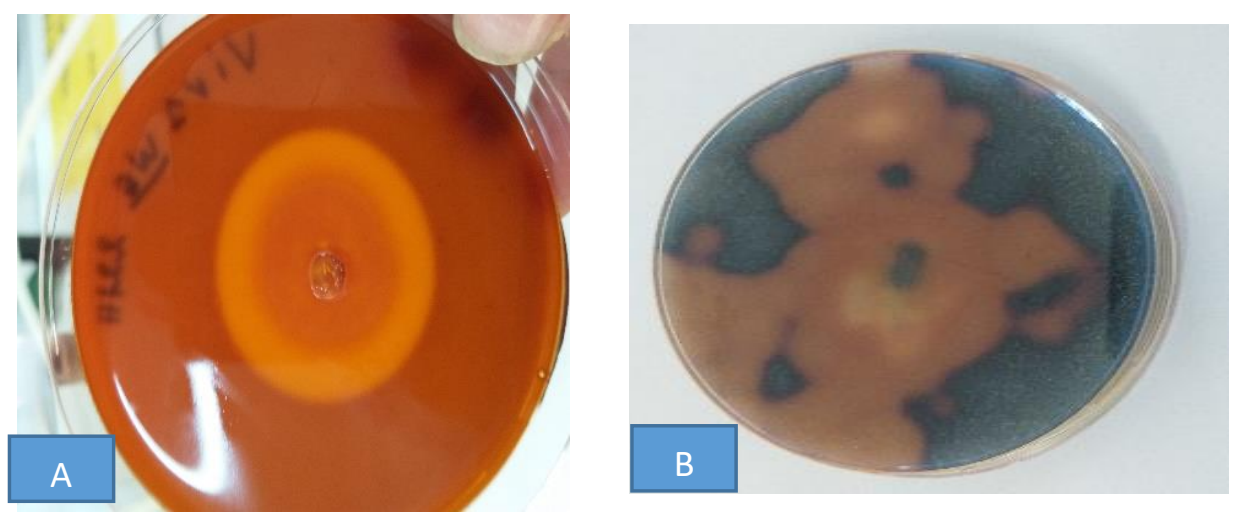

Figure 1: Detection of the enzyme activities using Petri diches containing specific mediums. (A) Cellulolytic activity, (B) Xylanolytic activity.

Table 1: Enzyme activity of fungal isolates on agar plates

\begin{tabular}{|c|c|c|}
\hline STRAIN & Cellulase & Xylanase \\
\hline TRC1 & - & - \\
\hline TRC2 & ++ & ++ \\
\hline TRC3 & - & - \\
\hline TRC4 & +++ & +++ \\
\hline TRC5 & ++ & ++ \\
\hline TRC6 & + & ++ \\
\hline TRC7 & - & - \\
\hline TRC8 & + & + \\
\hline TRC9 & + & + \\
\hline TRC10 & + & + \\
\hline TRC11 & ++ & ++ \\
\hline TRC12 & - & - \\
\hline TRC13 & - & - \\
\hline TRC14 & - & - \\
\hline TRC15 & - & - \\
\hline TRC16 & +++ & +++ \\
\hline ALT1 & +++ & $+/-$ \\
\hline ALT2 & ++ & + \\
\hline ALT3 & - & - \\
\hline ALT4 & + & - \\
\hline ALT5 & +++ & +++ \\
\hline FUS1 & - & - \\
\hline FUS2 & - & - \\
\hline VOB1 & +++ & +++ \\
\hline CLD1 & +++ & + \\
\hline CUV1 & + & + \\
\hline CUV2 & + & - \\
\hline PNC1 & +++ & +++ \\
\hline PNC2 & ++ & $+/-$ \\
\hline PNC3 & ++ & + \\
\hline APS1 & +++ & +++ \\
\hline APS2 & +++ & +++ \\
\hline APS3 & +++ & +++ \\
\hline APS4 & - & - \\
\hline APS5 & - & - \\
\hline APS6 & - & $+/-$ \\
\hline APS7 & - & - \\
\hline APS8 & - & $+/-$ \\
\hline APS9 & - & - \\
\hline APS10 & - & - \\
\hline
\end{tabular}


Among the 40 strains, 23 strains showed a cellulase activity, 18 are capable to produce xylanase. The perceptual distribution of the hydrolytic enzyme production among the 40 tested fungi was presented in figure 2 .

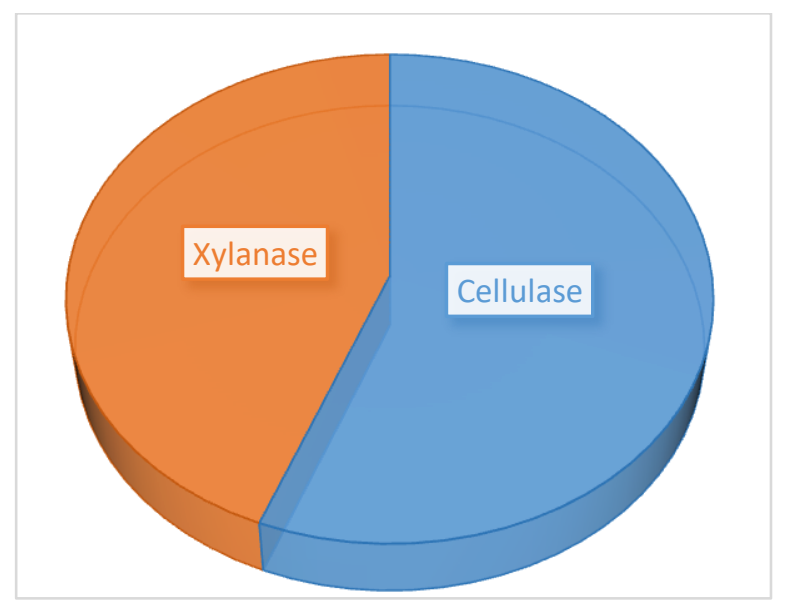

Figure 2: Percentage of fungal isolates according to its hydrolytic activities.

The figure 2 confirms that from 40 strains isolated, 56\% presented cellulolytic activity. Of these, isolates TRC4 (Trichoderma sp), TRC16 (Trichoderma sp), ALT1(Alternaria sp), ALT5 (Alternaria sp), VOB1 (Beauveria sp), CLD1 (Cladosporium sp), PNC1 (Penicillium sp), APS1 (Aspergillus $\mathrm{sp}$ ), APS2 (Aspergillus sp) and APS3(Aspergillus sp) presented a larger hydrolysis zone, which suggest that these fungi have higher cellulase activity than the other isolates. TRC2 (Trichoderma sp), TRC5 (Trichoderma sp), TRC11 (Trichoderma sp), ALT2 (Alternaria sp), PNC3 (Penicillium sp), PNC2 (Penicillium sp) have moderate activity and TRC8 (Trichoderma sp), TRC9 (Trichoderma sp), TRC10 (Trichoderma sp) TRC6 (Trichoderma sp), ALT4 (Alternaria $\mathrm{sp})$, CUV1(Culvularia sp), CUV2 (Culvularia sp) with low activity.

For the xylanase production, $44 \%$ of the isolates showed positive results: TRC4 (Trichoderma sp), ALT5 (Alternaria $\mathrm{sp})$, VOB1 (Beauveria sp), PNC1 (Penicillium sp), APS1 (Aspergillus sp), ASP2 (Aspergillus sp), ASP3 (Aspergillus sp) presented larger halos in the solid media, indicating higher xylanolyitc activity of these isolates. While TRC2 (Trichoderma sp), TRC5 (Trichoderma sp), TRC6 (Trichoderma sp), TRC11 (Trichoderma $\mathrm{sp}$ ) have moderate activity and CLD11 (Cladosporium sp), ALT2 (Alternaria sp), CUV1 (Culvularia sp), PNC3 (Penicillium sp), TRC8 (Trichoderma sp), TRC9 (Trichoderma sp), TRC10 (Trichoderma sp) with low activity.

For quantitative estimation, Trichoderma sp (TCR6) produced maximum cellulase $(5,10 \mathrm{UI} / \mathrm{ml})$ and xylanase with (98,25UI/ML) although she is not among the strains that presented larger hydrolysis zone. Xylanase activity is high compared to cellulase because hemicelluloses are the most easily polysaccharide compounds hydrolyzed of the plant cell wall28.

The cellulases term refer to a group of enzymes that catalyze the hydrolysis of cellulose into sugars. Cellulolytic microorganisms play an important role in the biosphere by recycling cellulose, the most abundant carbohydrate produced by plants 29 . Cellulases are widely used such as in the food, fuel, textiles, pulp and paper industries ${ }^{30,31}$.

According to Girio et al (2010) ${ }^{32}$; Selvam et al (2014) ${ }^{33}$; Kandasamy (2016) ${ }^{34}$ xylans are the predominant compounds in the hemicellulose fraction, it is depolymerized to xylose and other sugars by xylanases (E.C. 3.2.1.8) who are hydrolytic enzymes with wide applications in several industries, such as biofuels, paper, deinking, food and feed ${ }^{35}$.

Fungi like Trichoderma sp secrete a large number and a variety of enzymes that can act the polycassharides found in plant cell walls. These enzymes include cellulases, hemicellulases, pectinases, esterases, oxidoreductases and proteases ${ }^{36}$. Xylanases are among the most known enzymes; therefore, this fungal genus is suited for further examination of function and application of these enzymes ${ }^{37}$.

Trichoderma reesei Rut C-30 is the most wellnown Trichoderma strain producing several xylanases and cellulases with different biochemical properties and specificities for substrates, as predicted by genome sequence 38 , and also many enzyme preparations obtained from the large-scale cultivation of this fungus have been commercialized. Xylanases from other Trichoderma species have also been studied as those from Trichoderma harzianum, Trichoderma lignorum, Trichoderma longibrachiatum, Trichoderm koningii, Trichoderma pseudokoningii and Trichoderma viride 39,40 .

The polysaccharides especially celluloses and hemicelluloses are very cheap and easily available as wastes from industries, like paper and pulp, agriculture, food and feed and municipal. In developing countries these wastes are not been discarded or treated properly and become the major cause of environmental pollution ${ }^{2}$.

Nineteen strains; TRC2 (Trichoderma sp), TRC4

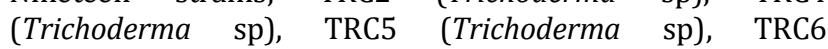

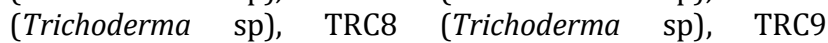
(Trichoderma sp), TRC10 (Trichoderma sp), TRC11 (Trichoderma sp), TRC16 (Trichoderma sp), ALT1 (Alternaria $\mathrm{sp}$ ), ALT2 (Alternaria sp), ALT4 (Alternaria sp), ALT5 (Alternaria sp), VOB1 (Beauveria sp),CLD1(Cladosporium sp),CUV1 (Culvularia sp), CUV2 (Culvularia sp), PNC1 (Penicillium sp), PNC2 (Penicillium sp), PNC3 (Penicillium sp), APS1 (Aspergillus sp), APS2 (Aspergillus sp), APS3 (Aspergillus $\mathrm{sp}$ ) produced the two lignocellulolytic enzymes (cellulase and xylanase).

Fifteen isolates:TRC1 (Trichoderma sp), TRC3 (Trichoderma sp), TRC7 (Trichoderma sp),TRC12 (Trichoderma sp),TRC13 (Trichoderm sp), TRC14 (Trichoderma sp), TRC15 (Trichoderma sp), ALT3 (Alternaria sp), FUS1 (Fusarium sp), FUS2 (Fusarium sp), APS4 (Aspergillus sp), APS5 (Aspergillus sp), APS7 (Aspergillus sp), APS9 (Aspergillus sp), APS10 
(Aspergillus sp) were non producers of any of the lignocellulolytic enzymes studied. However, a negative result does not confirm the inability of a strain to produce the enzyme. This mean that the medium is inadequate for the detection of the enzyme, or the enzyme has not been released from the mycelium ${ }^{41}$.
Fungi in general are well characterized microorganisms due to their capacity to produce a wide range of enzymes to digest complex materials in the environment into solubilized breakdown products that can be up taken into the hyphae and used as nutrients for surviving ${ }^{42}$.
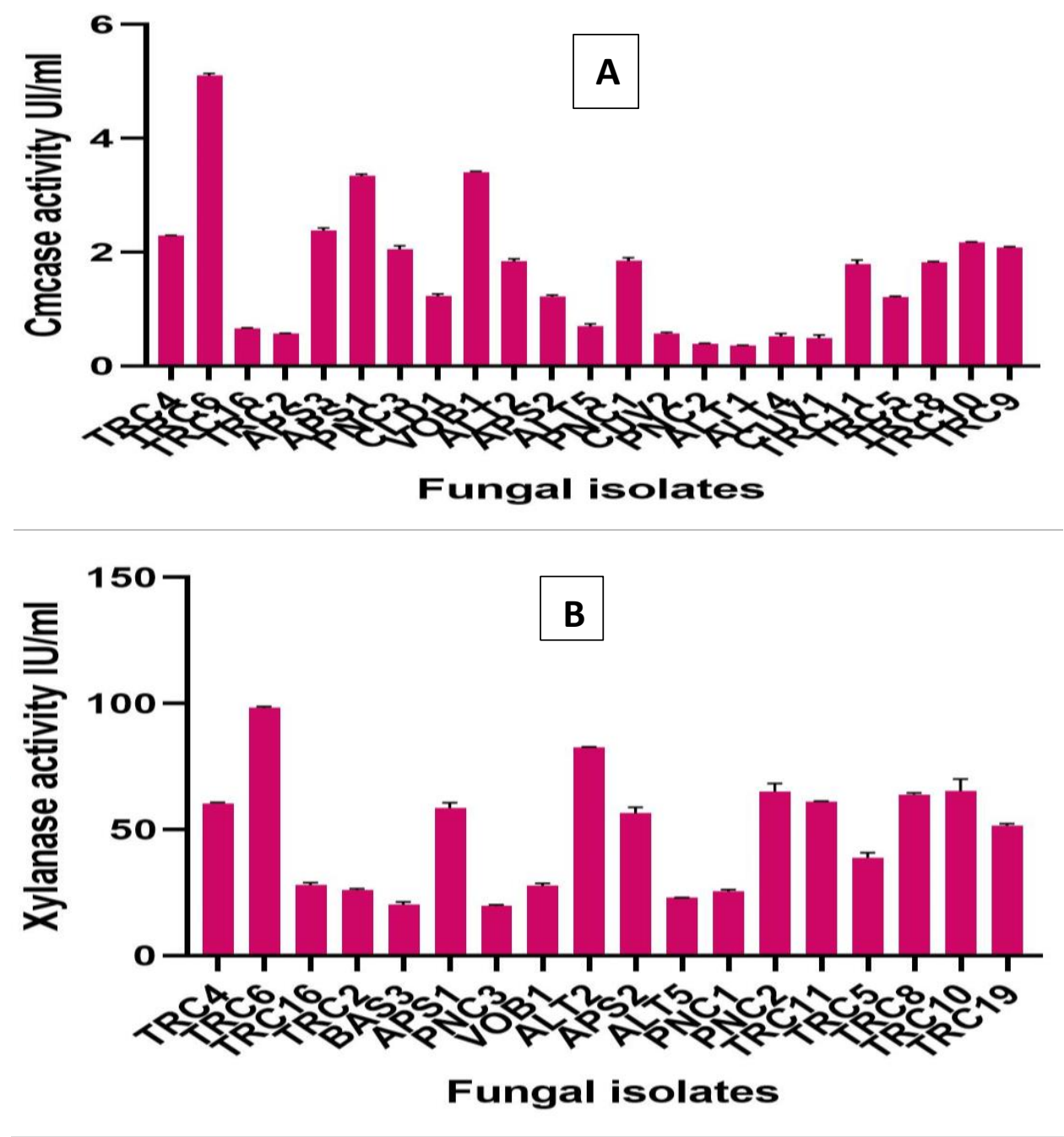

Figure 3. The lignocellulolytic enzymes activities of fungal isolates.

A: Cellulolytic activity, B: Xylanolytic activity.

\section{CONCLUSION}

In present study, forty different fungal isolates from rich soil in organic matter were screened for the presence of lignocellulolytic cextracellular enzymes such as cellulase and xylanase which has grown on specific mediums (qualitative activity) and under submerged fermentation (quantitative activity). The order of enzymes activities found in this study with percentage for the isolated microorganisms are cellulolytic then xylanolytic. For cellulase and xylanase activities, the highest producing strain was Tricoderma sp. Based on these results; this strain has a major role in the degradation of organic matter.

\section{ACKNOWLEDGEMENTS}

The authors acknowledge the Algerian Ministry of Higher Education and Scientific Research (MESRS) and the General Directorate of Scientific Research and Technological Development (DGRSDT) for their financial support.

\section{REFERENCES}

1. Li JX, Zhang F, Jiang DD, et al, « Diversity of Cellulase-Producing Filamentous Fungi From Tibet and Transcriptomic Analysis of a Superior Cellulase Producer Trichoderma harzianum LZ117, Front Microbiol, 2020; 11:1617.

2. Dashtban M, Schraft H, Qin W, « Fungal bioconversion of lignocellulosic residues; Opportunities \& perspectives» International Journal of Biological Sciences, 2009, 5:578-595.

3. Cunha L, Martarello R, de Souza PM, et al, « Optimization of Xylanase Production from Apergillus foetidus in Soybean Residue » Enzyme Research, 2018, 17:1-7.

4. Plempel M, Bremm, kD, Gao, Z, «Pathogenese -Faktoren von Dermatophyten» German Patent Aplication, 1991.

5. Vinod KN, Mary ER, Gunaseeli R, et al, « Process optimization and production kinetics for cellulase production by Trichoderma viride VKF3» Springer Plus, 2014; 3(1):92.

6. Tasia W, Melliawati R, «Cellulase and xylanase production from three isolates of indigenous endophytic fugi » Earth and Enviromental Science, 2017; 1-5.

7. Demain, AL, Adrio, JL, « Contributions of microorganisms to industrial biology » Molecular Biotechnology, 2008; 38:41-55. 
8. Polizeli M, Rizzatti A, Monti R, et al, « Xylanase from fungi: Properties and industrial application» Applied Microbiology and biotechnology, 2005; 67(5):577-591.

9. Bhat $\mathrm{MK}$, "Cellulases and related enzymes in biotechnology » Biotechnol Adv, 2000; 18(5):355-383.

10. Kuhad RC, Gupta R, Singh A « Microbial cellulases and their industrial applications» Enzyme Research, 2011; 20:11-24.

11. Subramaniyan S, Prema « Biotechnology of microbial xylanases: Enzymologie, molecular biology,and application " Critical Reviews in Biotechnology, 2002; 22(1):33-64.

12. Limayem A, Rike SC « Lignocellulosic biomass for bioethanol production: Curent perspectives, potential issues and future prospects » Progress in Energy and combustion science, 2012; 38(4):449-467.

13. Sankareswaran M, Kalaiselvi K, Anbalagan S, et al, « Production, cahracterisation and immobilized dye decolorization of amylase enzyme produced by Bacillus megabacterium isolated from soil sample " International Journal of advanced Research, 2015; 3:295-305.

14. Choi Y, Hodgkiss JJ, Hyde D, « Enzyme production by endophytes of Brucea javanica » Journal of Agriculture Science and Technology, 2005; 1:55-66.

15. Jahangeer $\mathrm{S}$, Khan $\mathrm{N}$, jahangeer $\mathrm{S}$, et al, « Screening and characterization of fungal cellulase isolated from the native environmental source » Pakistan Journal of Botany, 2005; 37(3), 739-748.

16. Maria GL, Sridhar KR and Raviraja NS, «Antimicrobial and enzyme activity of mangrove endophytic fungi of southwest coast of India » Journal of Agricultural Science and Technology, 2005; 1: 67-80.

17. Taeochapoempol K, Sreethawong $\mathrm{T}$, Rangsunvigit $\mathrm{P}$, et al, « Cellulase-Producing Bacteria from Thai Higher Termites, Microcerotermes sp.: Enzymatic Activities and Ionic Liquid Tolerance» Applied biochemistry and biotechnology, 2011; 164(2):204-219.

18. Gautam SP, Bundela PS, Pandey AK, et al, « Optimization for the production of cellulase enzyme from municipal solid waste residue by two novel cellulolytic fungi » Biotechnology Research International, 2011; 1: 1-8.

19. Wongpisal P, Aundre KN, Seephueak P, et al, « Effect of fungi for decomposition rate and nutrient content in oil palm leaf litter (Elaeis guineensis Jacq.) Songklanakarin» Journal of Plant Science, 2016; 3:9-14.

20. Naveen Kumar KJ, Thippeswamy B, « Isolation and screening of potential cellulolytic fungi from Areca nut husk waste» International Journal of Current Science, 2013; 8 :125-132.

21. Mandels M, Weber J, « The production of cellulases. In Cellulases and their Applications » Advances in Chemistry Series, (ed. R. F. Gould), Washington, DC: American Chemical Society, 1969; 95:391-414.

22. Pointing SB, «Qualitative methods for the determination of lignocellulolytic enzyme production by tropical fungi » Fungal Diversity, 1999; 2:17- 33.

23. Philippoussis A, Diamantopoulou P, Papadopoulou K, et al, « Biomass, laccase and endoglucanase production by Lentinula edodes during solid state fermentation of reed grass, bean stalks and wheat straw residues » World Journal of Microbiology and Biotechnology, 2011; 27(2):285-297.

24. Chakraborty S, Gupta R, Jain KK, et al, « Cost-effective production of cellulose hydrolysing enzymes from Trichoderma sp. RCK65 under SSF and its evaluation in saccharification of cellulosic substrates » Bioprocess and Biosystems Engineering, 2016; 39: 1659-1670.

25. Ghose TK, « Measurement of cellulase activities» Pure and Applied Chemistry, 1987; 59:257-268.

26. Miller GL, «. Use of dinitrosalicyclic acid reagent of determination of reducing sugar. Analytical Chemistry, 1959; 31:426-429.

27. Favaro L, Jooste T, Basaglia M, et al, « Designing industrial yeasts for the consolidated bioprocessing of starchy biomass to ethanol » Bioengineered, 2013; 4(2):97-102.

28. Flannigan B, « Degradation of arabinoxylan and carboxymethyl cellulose by fungi isolated from barley kernels » Transactions of the British Mycological Society, 1970; 55:277-281.

29. Kasana RC, Salwan, R, Dhar H, et al, «A Rapid and easy method for the detection of microbial cellulases on agar plates using Gram's iodine» Current Microbiology, 2008; 57:503-507.

30. Bano A, Chen X, Prasongsuk S, et al, «Purification and characterization of cellulase from obligate halophilic Aspergillus flavus (TISTR 3637) and its prospects for bioethanol production» Appl Biochem Biotechnol, 2019; 189:1327-1337.

31. Girio FM, Fonseca C, Carvalheiro F, et al, « Hemicelluloses for fuel ethanol: A review. Bioresour Technol, 2010; 101(13):47754800 .

32. Selvam K, Govarthanan M, Kamala-Kannan S, et al « Process optimization of cellulase production from alkali-treated coffee pulp and pineapple waste using Acinetobacter sp. TSK-MASC» RSC Advanes, 2014; 4:13045-13051.

33. Kandasamy S, Muthusamy G, Balakrishna S, et al, « Optimization of protease production from surface-modified coffee pulp waste and corncobs using Bacillus sp. by SSF» 3 Biotech, 2016; 6(2): 167.

34. Azzouz Z, Bettache A, Boucherba N, et al, «Optimization of xylanase production by newly isolated strain trichoderma afroharzianum isolate az 12 in solid state. fermentation using response surface methodology " Cellulose chemistry and technology, 2020; 54 (5-6):451-462.

35. Chandra M, Kalra A, Sharma PK, et al, « Optimization of cellulases production by Trichoderma citrinoviride on marc of Artemisia annua and its application for bioconversion process » Biomass and Bioenergy, 2010, 34:805-811.

36. Wong KKY, Saddler JN, Trichoderma xylanases, their properties and application, Crit Rev Biotechnol, 1992; 12:413-435.

37. Peterson R, Nevalainen $\mathrm{H}$, « Trichoderma reesei RUT-C30- Thirty years of strain improvement» Microbiology, 2012; 158: 58-68.

38. Silveira FQP, Sousa MV, Ricart CAO, et al, new xylanase from a Trichoderma harzianum strain, J Ind Microbiol Biotechnol, 1999; 23:682-685.

39. Chen LL, Zhang M, Zhang DH, et al, « Purification and enzymatic characterization of two $\beta$-endoxylanases from Trichoderma sp. K9301 and their actions in xylooligosaccharide production » Bioresour Technol, 2009; 100:5230-5236.

40. Rajaa C, Franck D, Christelle D, et al, «Isolation, Identification and enzymatic activity of halotolerant and halophilic fungi from the great Sebkha of Oran in Northwestern of Algeria. Mycobiology, 2019; 47(2):230-241.

41. Webster J, Weber RWS, «Introduction to fungi, Cambridge University Press, 3rd ed: 2007; 875. 